\title{
Freshwater Snails and Schistosomiasis Mansoni in the State of Rio de Janeiro, Brazil: I - Metropolitan Mesoregion
}

\author{
Silvana C Thiengo, Monica A Fernandez, M Fernanda Boaventura, \\ Carlos E Grault*, Heucler FR Silva**, Aline C Mattos, Sonia B Santos***
}

\begin{abstract}
Departamento de Malacologia, Instituto Oswaldo Cruz-Fiocruz, Av. Brasil 4365, 21045-900 Rio de Janeiro, RJ, Brasil *Departamento de Ciências Biológicas, Escola Nacional de Saúde Pública-Fiocruz, Rio de Janeiro, RJ, Brasil

**Secretaria Estadual de Saúde, Rio de Janeiro, RJ, Brasil *** Instituto de Biologia Roberto Alcântara Gomes, Laboratório de Malacologia, Universidade do Estado do Rio de Janeiro, Rio de Janeiro, RJ, Brasil
\end{abstract}

In order to elaborate a planorbid chart of the State of Rio de Janeiro a survey of freshwater gastropods in the Metropolitan Mesoregion of this State was performed and revealed the occurrence of 20 species: Antillorbis nordestensis (Lucena, 1954); Biomphalaria glabrata (Say, 1818); Biomphalaria schrammi (Crosse, 1864); Biomphalaria straminea (Dunker, 1848); Biomphalaria tenagophila (Orbigny, 1835); Burnupia sp.; Drepanotrema anatinum (Orbigny, 1835); Drepanotrema cimex (Moricand, 1839); Drepanotrema lucidum (Pfeiffer, 1839); Ferrissia sp.; Gundlachia ticaga (Marcus \& Marcus, 1962); Heleobia davisi Silva \& Thomé, 1985; Lymnaea columella Say, 1817; Melanoides tuberculatus (Müller, 1774); Physa cubensis Pfeiffer, 1839; Physa marmorata Guilding, 1828; Pomacea sp.; Pomacea canaliculata (Lamarck, 1822); Pomacea lineata (Spix, 1827) and Pomacea sordida (Swainson, 1823). Among the planorbid species B. tenagophila was the most frequent, occurring in all municipalities surveyed. The present study extends the distribution of $\mathrm{B}$. straminea in the State of Rio de Janeiro and reports new records for A. nordestensis, B. schrammi, G. ticaga, H. davisi and the genera Burnupia and Ferrissia. An account about the current transmission areas of schistosomiasis mansoni in this Mesoregion is presented as well.

Key words: freshwater snails - schistosomiasis mansoni - vectors - cercariae - Rio de Janeiro - Brazil

Papers concerning surveys of freshwater snails in Brazil are still scarce in spite of the diversity of species and the importance of some of them to Public Health: Luz et al. (1998), Morretes (1949), Paraense (1983), Paraense et al. (1983), Vaz et al. (1987), Souza et al. (1998) and Thiengo et al. (1998).

In order to elaborate a chart of planorbids of the State of Rio de Janeiro, collecting was done during the last three years in the following municipalities of the Metropolitan Mesoregion of the State: Engenheiro Paulo de Frontin, Mendes, Miguel Pereira, Paracambi, Paty do Alferes and Vassouras (Microregion Vassouras); Cachoeiras de Macacu and Rio Bonito (Microregion Macacu-

The authors dedicate this paper to the Oswaldo Cruz Institute in honor of the centenary of its foundation, May 25th 1900.

Financial support: $\mathrm{CNPq} /$ Fiocruz, Faperj/Fiocruz

${ }^{+}$Corresponding author. Fax: +55-21-2280.5840. E-mail: sthiengo@ioc.fiocruz.br

Received 14 May 2001

Accepted 25 July 2001
Caceribu); Itaguaí and Mangaratiba (Microregion Itaguaí); Belford Roxo, Duque de Caxias, Itaboraí, Japeri, Maricá, Nilópolis, Niterói, Nova Iguaçu, Queimados, Rio de Janeiro, São Gonçalo and São João de Meriti (Microregion Rio de Janeiro).

Data concerning Petrópolis, São José do Vale do Rio Preto and Teresópolis (Microregion Serrana) and the municipalities of Magé and Guapimirim (Microregion Rio de Janeiro) were previously published elsewhere (Thiengo et al.1998).

A list of freshwater snail species of the above mentioned area is presented, based on material collected by the authors and on the collection of the Department of Malacology of Instituto Oswaldo Cruz (CMIOC). An account about the transmission areas of schistosomiasis mansoni in this Mesoregion, a map showing the distribution of the species of medical and veterinary importance and a survey of the different kinds of cercariae found are presented as well.

\section{MATERIALS AND METHODS}

We follow the Brazilian Institute of Geography and Statistic (IBGE 1995) which divides politically and administratively the State of Rio de Janeiro into 
81 municipalities arranged in 6 mesoregions and 18 microregions.

The molluscs were collected from different suitable snail habitats (streams, rivers, marsh areas, drainage and sewage ditches, ponds, flood areas and irrigation canals) in all 61 districts of the 22 municipalities in the surveyed area. Since three different habitats were investigated in each of the districts, an average of 183 samples were obtained.

Live snails were kept at the laboratory for a month in aquaria containing dechlorinated tap water and, at the bottom, a thin layer of a 2:1 mixture of screened soil and ground oyster shells as a source of mineral nutrients. Snails were fed fresh lettuce leaves. In the meantime, all specimens were exposed to artificial light in intervals of five days to determine possible infection with trematode larvae. The cercariae were fixed in $70 \%$ ethanol, stained with chloridric carmine and mounted in Canada balsam, using Shell (1970) for identification.

The ten larger specimens of each sample were preserved in Railliet-Henry's fluid after relaxation in a $0.05 \%$ nembutal solution and two of them were dissected under a stereomicroscope for identification.

Samples of taxonomic importance were deposited at the Malacological and Helminthological Collections of Instituto Oswaldo Cruz.

Parasitological stool surveys, employing the Kato-Katz method (Katz et al. 1972), were carried out in three localities of Rio de Janeiro City, in collaboration with National Health Foundation (Funasa).

The results of the parasitological survey from 1996 to the first trimester of 2000 were obtained in consolidated returns from Funasa, excluding Rio de Janeiro City where the positive cases from 1996 to 1998 were obtained from the Co-ordination of Epidemiology Programme of Health Secretary of Rio de Janeiro City.

\section{RESULTS}

The Table I comprises the localities where the species have been found in the surveyed area. The distribution of the three vectors of Schistosoma mansoni Sambon, 1907 and Lymnaea columella Say, 1817 is showed in the Figure.

In all, 8 species of planorbids and 12 other freshwater gastropods were found: Antillorbis nordestensis (Lucena, 1954); Biomphalaria glabrata (Say, 1818); Biomphalaria schrammi (Crosse, 1864); Biomphalaria straminea (Dunker, 1848); Biomphalaria tenagophila (Orbigny, 1835); Burnupia sp.; Drepanotrema anatinum (Orbigny, 1835); Drepanotrema cimex (Moricand, 1839); Drepanotrema lucidum (Pfeiffer, 1839); Ferrissia sp.; Gundlachia ticaga (Marcus \& Marcus, 1962);
Heleobia davisi Silva \& Thomé, 1985; L. columella; Melanoides tuberculatus (Müller, 1774); Physa cubensis Pfeiffer, 1839; Physa marmorata Guilding, 1828; Pomacea sp.; Pomacea canaliculata (Lamarck, 1822); Pomacea lineata (Spix, 1827) and Pomacea sordida (Swainson, 1823). The greatest variety of species was observed in the municipality of Maricá and Rio de Janeiro City.

Although different kinds of cercariae had been observed, no specimens were found infected with S. mansoni, as shown in the Table II. The major diversity of cercariae were found in B. tenagophila which was also the most parasited species. The Xiphidiocercariae group was the most frequent and it was found in all species of parasited molluscs, except for G. ticaga and M. tuberculatus. This latter presented only Pleurolophocercus cercariae, which has not yet been reported in Brazil.

The results of the parasitological survey from 1996 to the first trimester of 2000 are shown in Table III. In Rio de Janeiro City, the parasitological survey was performed in three localities recognised as potential transmission sites. In the locality of Santa Cruz, where stool examination began in 1996, 12 positive cases were found in that year, 8 in 1997, 4 in 1998, 15 in 1999 and 0 in 2000. Vargem Grande was the second locality studied and, 33 positive cases were detected in 1998, 44 in 1999 and 1 in 2000. In the locality of Alto da Boa Vista 36 were recorded in 1999 and 16 in 2000.

Concerning the snail host distribution in Alto da Boa Vista and Vargem Grande localities, only B. tenagophila was collected.

\section{DISCUSSION}

The most frequent species was B. tenagophila, occurring in all the localities surveyed. The occurrence of two natural vectors of $S$. mansoni, B. tenagophila and B. straminea, was observed in Duque de Caxias, Itaboraí, Mangaratiba, Maricá, Miguel Pereira, Niterói, Nova Iguaçu, Paracambi, Rio de Janeiro, São Gonçalo and Vassouras. Sintopy involving these species was observed only in Niterói. Magalhães (1964) reported the coexistence of B. tenagophila and B. glabrata in Manguinhos, on the Campus of Instituto Oswaldo Cruz. The same was observed by Grault et al. (1998) in three breeding sites in Santa Cruz, a locality in the west area of Rio de Janeiro City. We did not find B. glabrata in Santa Cruz, even after exhaustive sampling in the areas pointed out. The authors reported that the appearance of B. glabrata in B. tenagophila natural breeding sites occurred after a period of heavy rains, probably as a result of accidental introduction of B. glabrata into artificial ponds in Serra da Paciência hill range. Nowadays, although B. glabrata still occurs in three different breeding 
TABLE I

List of species and the localities where they were found in the Metropolitan Mesoregion of the State of Rio de Janeiro

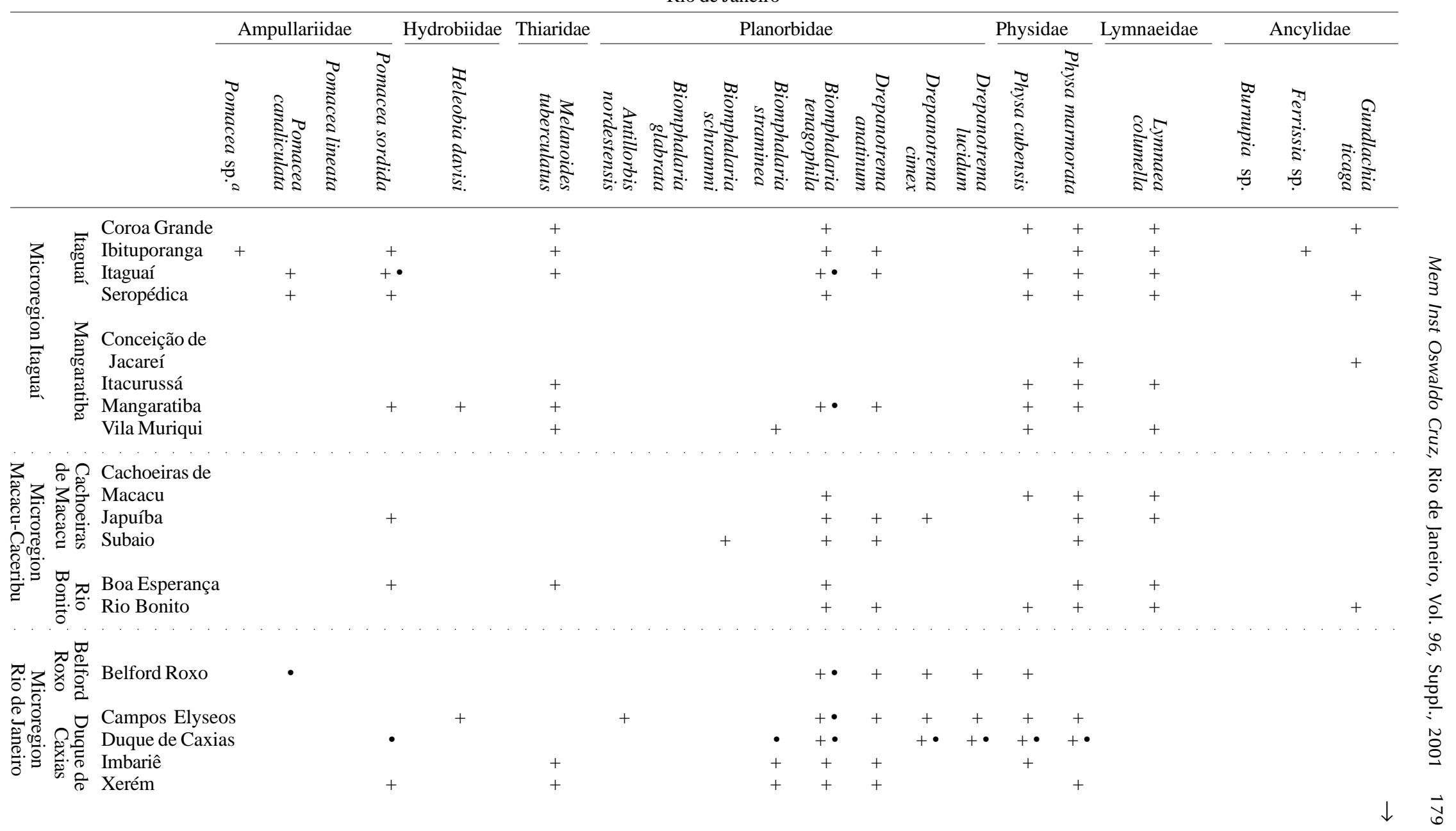




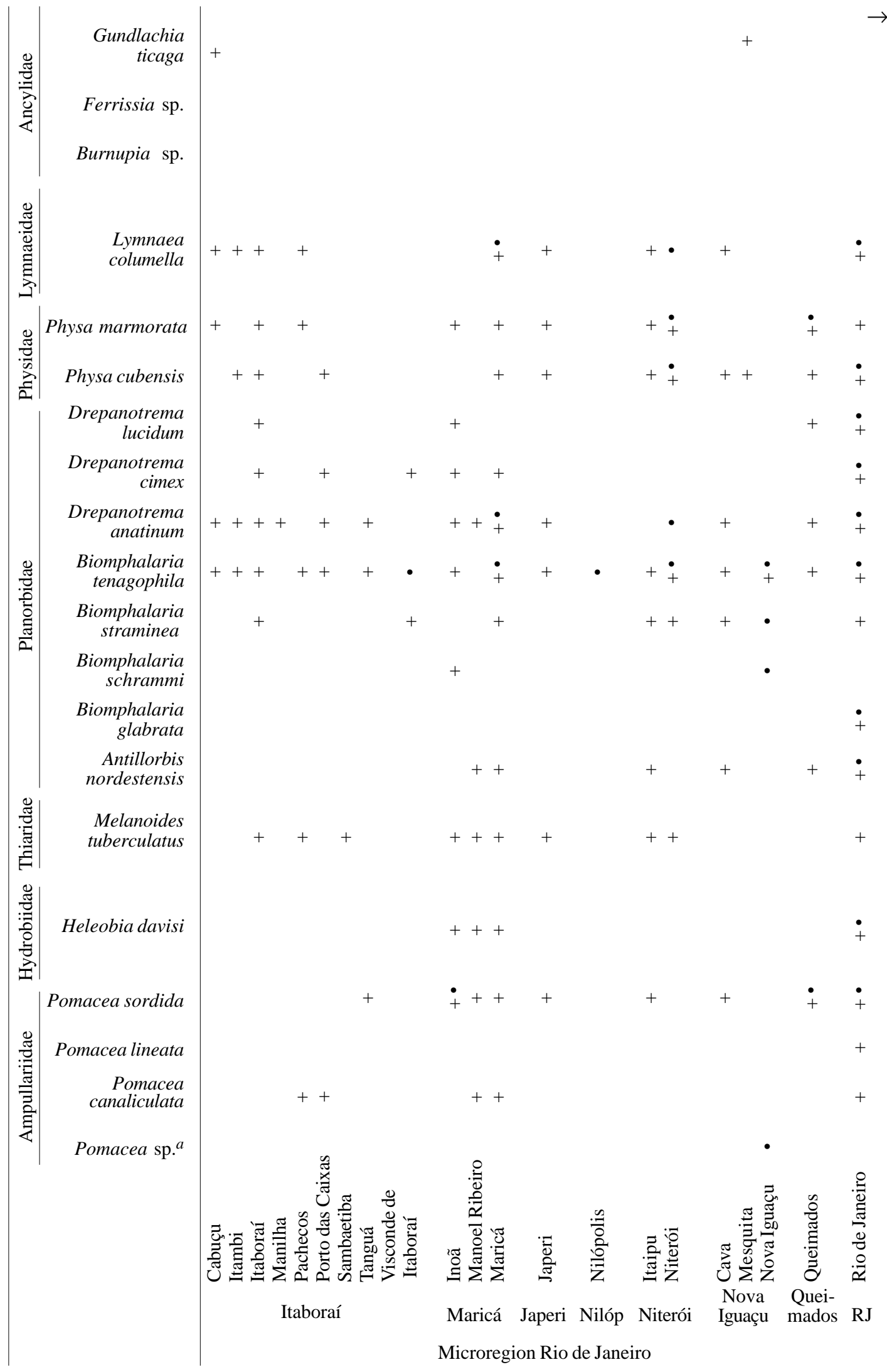




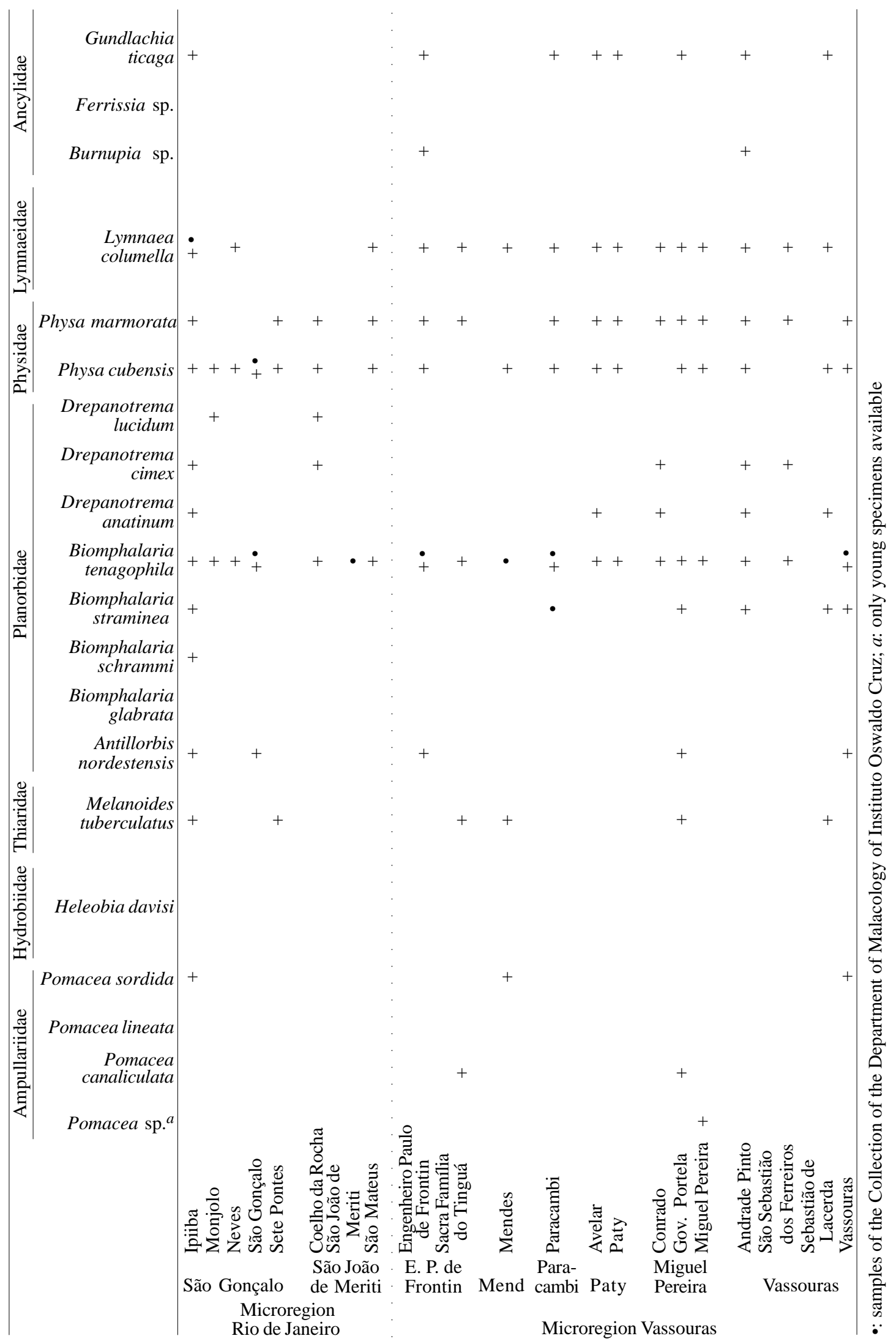


TABLE II

List of cercariae and the localities where they were found in the Metropolitan Mesorregion of the State of Rio de Janeiro

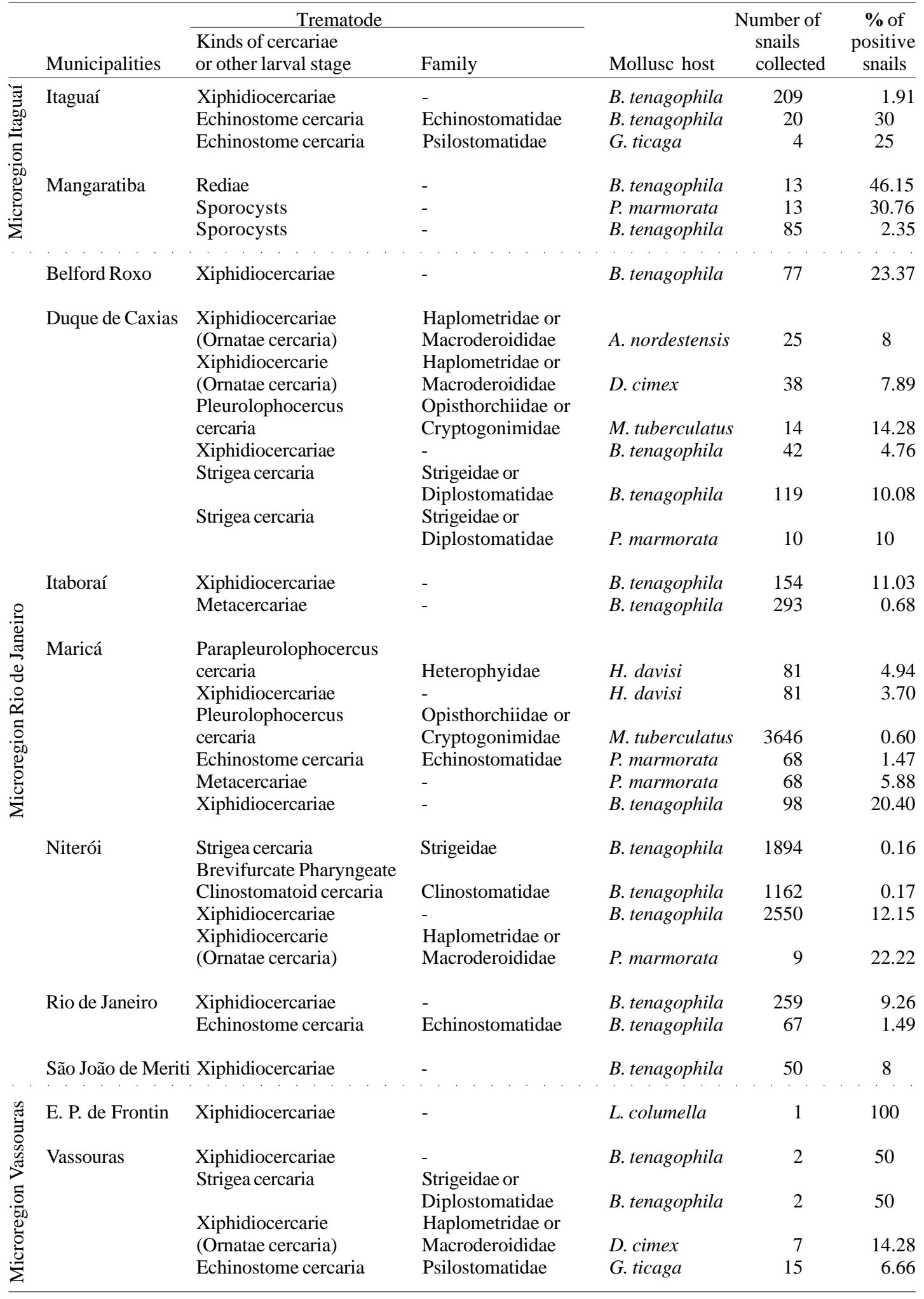


TABLE III

Number of positive cases of schistosomiasis in the Metropolitan Mesoregion

\begin{tabular}{|c|c|c|c|c|c|}
\hline \multirow[b]{2}{*}{ Municipality } & \multicolumn{5}{|c|}{ Year } \\
\hline & 1996 & 1997 & 1998 & 1999 & 2000 \\
\hline Belford Roxo & 1 & 8 & 1 & - & - \\
\hline Duque de Caxias & 3 & 1 & - & - & 1 \\
\hline Eng. Paulo de Frontin & - & 1 & - & 10 & 4 \\
\hline Itaboraí & - & - & - & 1 & - \\
\hline Itaguaí & 14 & 2 & 3 & - & - \\
\hline Mangaratiba & - & 7 & - & - & - \\
\hline Mendes & - & - & 1 & - & - \\
\hline Niterói & 9 & 14 & 9 & 13 & - \\
\hline Nova Iguaçu & 3 & 2 & 1 & - & 1 \\
\hline Paracambi & 40 & 39 & 47 & 82 & 8 \\
\hline Queimados & - & - & 1 & - & - \\
\hline Rio de Janeiro & 89 & 77 & 81 & 95 & 17 \\
\hline São Gonçalo & 3 & 15 & 13 & 15 & 1 \\
\hline São João de Meriti & - & 1 & - & - & - \\
\hline
\end{tabular}

sites on the Campus of Fundação Oswaldo Cruz, it is not found in sintopy with $B$. tenagophila.

The distribution of B. straminea in the State, previously known to Duque de Caxias, Guapimirim, Magé, Paracambi and Petrópolis (Paraense 1986, Thiengo et al.1998) was now extended to $14 \mathrm{mu}-$ nicipalities, as shown in the Figure. Concerning Paracambi, according to Silva et al. (1997) and the present investigation, only B. tenagophila occurs in that municipality nowadays. The possibility of disappearance of $B$. straminea as a result of competition with $B$. tenagophila is considered by the authors.

During this investigation we failed to find molluscs in Nilópolis probably due to environmental changes resulting from urbanism and the heavy pollution of the few waterbodies available. The record of B. tenagophila in Nilópolis was obtained from the collection (CMIOC 3009), sample collected in 1984. Similarly, B. schrammi from Nova Iguaçu was also obtained from the collection (CMIOC 82, from 1954), once this species was not found in this investigation.

The present study extended the geographical distribution of A. nordestensis and B. schrammi (Table I). So far only A. nordestensis was reported in two municipalities (Guapimirim and Petrópolis) of the State of Rio de Janeiro (Thiengo et al. 1998).

Concerning the non-planorbid gastropods, P. cubensis, P. marmorata and L. columella were the most frequent species in the surveyed area.

In relation to the Ancylidae, G. ticaga was the most common species, occurring in limpid as well as in polluted habitats. Along with Burnupia sp., it has been recorded for the first time in Rio de Janeiro. Previous reports in the country of Burnupia sp. were Espírito Santo, Alagoas, Rio Grande do Sul and Santa Catarina (Santos 1990, Lanzer 1991); and for Ferrissia sp., Rio de Janeiro, Rio Grande do Sul, Santa Catarina, Espírito Santo and Alagoas (Santos 1990, Lanzer 1991, Thiengo et al. 1998).

The asiatic thiarid M. tuberculatus was found in 14 out of the 22 municipalities, generally in areas with dense populations inhabiting lotic, lentic, polluted or limpid waterbodies. The most frequent ampullariid, $P$. sordida, originally described to São Cristovão, a neighborhood located in downtown Rio de Janeiro, seems to be more vulnerable to environmental changes resulted from urbanism, once it was collected only from limpid habitats in the peripheries of the municipalities. On the contrary, $P$. canaliculata inhabited even polluted breeding sites in urban areas. The only record of $P$. lineata was on the Campus of Fundação Oswaldo Cruz. The records of $H$. davisi here presented are the most northern distribution of this species, reported previously to the south of the country.

This paper reports M. tuberculatus, A. nordestensis and G. ticaga acting as intermediate hosts of trematodes in Brazil for the first time.

With regard to schistosomiasis, because of the limitation of logistic resources available to Funasa in the last ten years, the numbers of positive cases must be seen as underestimated information. The results of the coproscopical survey in Rio de Janeiro also indicate that appreciable transmission is continuing in the localities of Alto da Boa Vista and Vargem Grande, since both localities have been recognised as low transmission sites (Suassuna \& Coura 1969). In contrast with the latter two localities, Santa Cruz transmission has been reducing after intervention carried out by the local health authorities. 


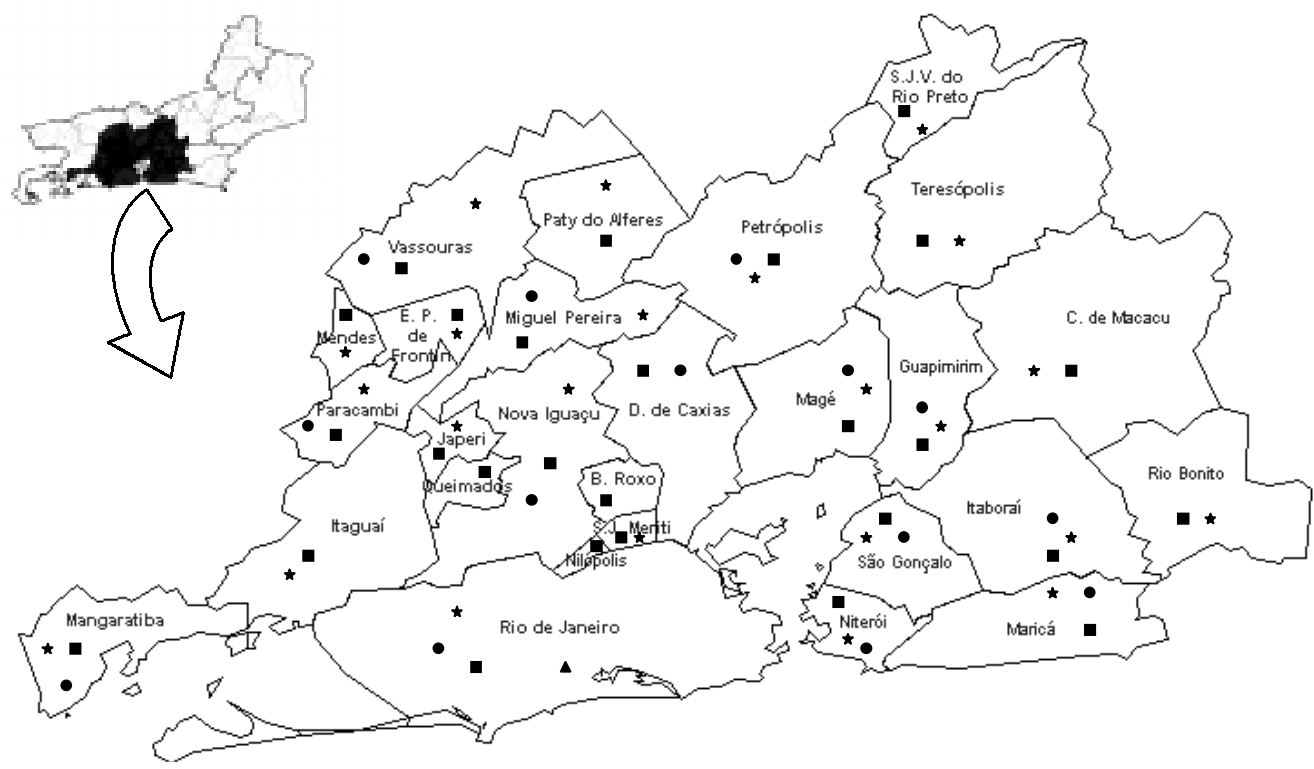

Map showing the distribution of the species of medical and veterinary importance.

(ロ) Biomphalaria tenagophila; (\)Biomphalaria straminea; $(\star)$ Lymnaea columella

\section{ACKNOWLEDGEMENTS}

To the Regional Directory of National Health Foundation of Rio de Janeiro (Funasa/RJ) in 1984, for sending us samples of snails from several localities of the State and to Dr WL Paraense, Head of Laboratory of Malacology, IOC-Fiocruz for the facilities supplied throughout this investigation.

\section{REFERENCES}

Grault CE, Mello-Silva CCC, Costa MJFS, Lenzi MF, Cruz OJ, Almeida AS, Silva MQ, Bezerra RMP, Costa V 1998. Mem Inst Oswaldo Cruz 93 (Suppl. I): $295-294$.

IBGE 1995. Síntese da documentação históricoadministrativa e geográfica dos Estados do Brasil Rio de Janeiro. Fundação Instituto Brasileiro de Geografia e Estatística, Rio de Janeiro.

Katz N, Chaves A, Pellegrino JP 1972. A simple device for quantitative thick-smear technique in schistosomiasis mansoni. Rev Inst Med Trop São Paulo 14: $397-400$

Lanzer RM 1991. Duas novas espécies de Ancylidae (Gastropoda: Basommatophora) para o sul do Brasil. Rev Brasil Biol 51: 703-719.

Luz E, Silva SM, Carvalho AP, Castro N 1998. Atualização da sistemática e distribuição geográfica dos planorbídeos (Gastropoda, Pulmonata) no Estado do Paraná (Brasil). Acta Biol Parasit 27: 39-55.

Magalhães LA 1964. Moluscos planorbídeos do Estado da Guanabara. Rev Bras Biol 24: 277-288.

Morretes FL 1949. Ensaio de Catálogo dos Moluscos do Brasil, Arquivo do Museu Paranaense, Curitiba, 7, 216 pp.

Paraense WL 1983. A survey of planorbid molluscs in the Amazonian Region of Brazil. Mem Inst Oswaldo Cruz 78: 343-361.
Paraense WL 1986. Distribuição dos caramujos no Brasil. In FA Reis, I Faria, N Katz (eds), Modernos Conhecimentos sobre Esquistossomose Mansônica, Biblioteca da Academia Mineira de Medicina, Belo Horizonte, p. 117-128.

Paraense WL, Alencar JTA, Corrêa LR 1983. Distribuição dos planorbídeos e prevalência da xistosomose mansoni no Estado do Espírito Santo. Mem Inst Oswaldo Cruz 78: 373-384.

Santos BS 1990. Sobre a presença de Burnupia Walker, 1912; Ferrissia Walker, 1903 e Laevapex Walker, 1903 no Brasil (Mollusca Basommatophora Ancylidae). An Acad Brasil Ci 62: 203.

Schell S 1970. How to Know the Trematodes, WMC Brown Co. Publishers, Dubuque, 355 pp.

Silva CLPAC, Soares SM, Barreto, MG 1997. Ocurrence of Biomphalaria tenagophila and disappearance of Biomphalaria straminea in Paracambi, RJ, Brazil. Mem Inst Oswaldo Cruz 92: 37-38.

Souza CP, Lima LC, Zannotti-Passos LK, Ferreira SS, Guimarães CT, Vieira LBF, Junior RJM 1998. Moluscos límnicos da Microrregião de Belo Horizonte, Minas Gerais, com ênfase nos vetores de parasitose. Rev Soc Bras Med Trop 31: 449-456.

Suassuna A, Coura JR 1969. Esquistossomose mansoni no Estado da Guanabara - Aspectos epidemiológicos relacionados as migrações internas. Rev Soc Bras Med Trop 3: 59-71.

Thiengo SC, Fernandez MA, Boaventura MFF, Stortti MA 1998. A survey of gastropods in the Microrregião Serrana of the Rio de Janeiro, Brazil. Mem Inst Oswaldo Cruz 93 (Suppl. I): 233-234.

Vaz JF, Elmor MRD, Gonçalves MC, Ishihata GK 1987. Resultados do levantamento planorbídico do Estado de São Paulo (Brasil): $4^{\mathrm{a}}$ região administrativa. Rev Saúde Públ (São Paulo) 21: 371-379. 